\title{
Päivi Kosonen
}

\section{Syntymäkertomuksen merkityssäikeitä}

Moderni omaelämäkerta ${ }^{2}$ voi alkaa syntymäkertomuksella (narrative of birth; récit de naissance), tekijän kertomuksella omasta tulemisestaan maailmaan. Se voi olla kirjaimellisesti kertomus omasta syntymästä, mutta usein se on vertauskuvallinen tai symbolinen kertomus. Kummassakin tapauksessa ihminen on kysymässä, mistä minun elämäni oikeastaan alkaa. Usein se on sen kysymistä, mistä minun elämäni alkaa, mutta modernin kysymyksen alla voi myös kuultaa toinen, perinteisempi kysymys: mistä tämä elämä alkaa. Tässä mielessä moderni omaelämäkertojakin on oman elämänsä mytografi.

Monissa kulttuureissa syntymä on muodostanut otollisen tilanteen elämän jäsentämiseen ja tulevaisuuden ennakointiin. Kaikki normaalista poikkeava on syntymän yhteydessä helposti pantu merkille ja ajateltu sen merkitsevän jotain. Esimerkiksi Suomalaisen Kansanrunousarkiston kätköistä kootut syntymätarinat kertovat äitien yrityksestä tulkita lastensa tulevaa elämää syntymämerkkien ja -enteiden pohjalta (Koivu 1982, 7-9). Vastaavan syntymää koskevan tulkintaprosessin voi ajatella olevan läsnä modernissa omaelämäkerrassa, jossa kertoja omasta syntymästään ja siinä ilmenevistä merkeistä käsin luo pohjaa oman elämänsä merkityksellistämiselle: elämänsä juonittamiselle.

Omalla syntymällä aloittamisen voi ajatella merkitsevän virittymistä omasta elämästään kertomiseen. Se on virittymistä oman elämän perimmäisille merkityssäikeille ja elämäntarinan punaiselle langalle - oman tarinan etsimiselle ja sen kertomiselle. Lukijalle rakenteellisesti tekstin alussa olevan syntymäkertomuksen voi vastaavalla tavalla ajatella tarjoavan virittymisen mahdollisuuden toisen elämään, toisen tapaan merkityksellistää elämäänsä ja sitä kautta taas lukijan omaa elämää (Marshall 1995).Vastaavasti kuin Philippe Lejeune aikoinaan hahmotteli omaelämäkertasopimusta (pacte autobiographique) omaelämäkerran "nuottiavaimena" (Lejeune 1971/1998, 49), ajattelen syntymäkertomuksen tällaisena omaelämäkerran yhtenä tekstuaalisena avainkohtana. Se on siis tekstikohta, jossa omaelämäkertoja avaa ääntään, valitsee äänensävynsä ja puherekisterinsä - ja muodostaa näin tarpeellista kontaktipohjaa tekijä-kertojan ${ }^{3}$ ja lukijan välille.

Tutkin seuraavassa omaelämäkerrallisia syntymäkertomuksia antiikista nykypäi- 
vään. Tarkemmin sanottuna syntymäkertomukset muodostavat tässä testiaineiston, jonka avulla pääsen tarkastelemaan kirjallisen omaelämäkertatutkimuksen lähtökohtaoletuksia. Philippe Lejeunen esittää (Lejeune 1975; Lejeune 1971/1998, 29-30) väitteen, että moderni, 1700-luvulla muotoutunut omaelämäkerta muodostaa radikaalin katkoksen suhteessa varhaisempaan omaelämäkertaan. Kirjoitukseni liittyy aikaisempaan tutkimustyöhöni modernin omaelämäkertalajin parissa (Kosonen 1995; Kosonen 2000). Kysyn, näkyykö omaelämäkerrallisissa aineistossa jälkiä tällaisesta katkoksesta.

\section{Syntymään liittyvät tähdet, merkit ja enteet}

Klassisen Kreikan omaelämäkerroissa syntymäpäivää ei yleensä mainita, elämäkerroissa toisinaan (Misch 1907/1973, 163). Roomalais-hellenistisessä (oma)elämäkerrallisessa kirjallisuudessa syntymäpäivä voidaan kuitenkin mainita. Antiikissa astrologia oli arvostettu, jokapäiväinen ja koko kulttuurin läpäisevä elämänalue, ja tähtien - erityisesti syntymähetken tähtien asennon - uskottiin vaikuttavan ihmisen elämänkulkuun.

Tämän käsitystavan ja uskomuksen mukaisesti ja sitä hyväksi käyttäen keisari Augustus (63ekr-14jkr) kirjoitti muistelmissaan syntymäänsä liittyvistä ihmeistä ja näyistä. Keisarin tarkoitus oli todistaa ja oikeuttaa oma jumalallisuutensa eli käytännössä oma yksinvaltansa. Hän oli Jumalaksi korotetun (= Julius Caesarin) adoptiopoika, Divi filius, mutta myös jo syntymässään valittu. (Misch 1907/1973, 263). ${ }^{4}$

Myös roomalais-hellenistiset biografit tekivät selkoa ihmisen elämään vaikuttavista merkeistä ja enteistä, kuten syntymähetken tähtien asennoista. Suetonius (n. 69-140) kuvaa tarkkaan Augustuksen syntymän ajankohdan ja paikan (1960, 63). Biografin tekijäkuvaa ja persoonaa luonnehdittaessa tavataan mainita hänen taikauskonsa samoin kuin hänen Rooman keisarien elämäkerroissaan ${ }^{5}$ (De vita Caesarum) mainitsemansa yliluonnolliseen liittyvät asiat: ihmeet ja enteet. Mutta myös Plutarkhos (n. 45-n.125) noteeraa enteet ja onnen tähdet esimerkiksi Sullan elämäkerrassa. Ciceron elämästä kirjoittaessaan hän myös pysähtyy pohdiskelemaan ennustusten merkitystä:

Mainitaan lisäksi, että Ciceron synnytys oli hänen äidilleen harvinaisen tuskaton ja helppo ja että hänen syntymäpäivänsä oli tammikuun kolmas, sama päivä, jona nyt hallitus uhraa ja rukoilee keisarin menestyksen puolesta. Kerrotaan hänen imettäjänsä nähneen henkiolennon, joka hänelle ilmoitti hänen imetettävänään olevan pojan tuottavan kerran Roomalle suurta siunausta. Tällaiset ennustukset ovat muutoin usein vain unia ja taruja, mutta lyhyessä ajassa Cicero osoitti, että ne myös voivat pitää paikkansa. (Plutarkhos 1989, 141)

Syntymään liittyvä tähtikartta on myös modernin omaelämäkerran motiivi. Esimerkiksi Goethe (1749-1832) antaa omaelämäkerrassaan Tarua ja totta elämästäni (1956; Aus meinem Leben. Dichtung und Wahrheit, 1811-33) yksityiskohtaisen selvityksen syntymäpäivänsä tähtien asennosta: 
Elokuun 28:ntena 1749, puolenpäivän aikaan kellon kahtatoista lyödessä, synnyin maailmaan Frankfurtissa Mainin varrella. Tähtienteet olivat onnekkaat: aurinko oli Neitsyen merkissä ja korkeimmillaan sinä päivänä, Jupiter ja Venus silmäilivät sitä ystävällisesti, Merkuriuskaan ei ynseästi, Saturnus ja Mars pysyttelivät välinpitämättömänä, ja yksin kuu, joka oli vast’ikään täyttynyt, vaikutti vastakkaisvalollansa sitäkin voimakkaammin, kun oli samalla tullut sen planeettahetki. Nämä hyvät merkit, joita astrologit myöhemmin osasivat selittää minulle erittäin edullisesti, lienevät olleet syynä pelastumiseeni; kätilön taitamattomuuden vuoksi minä näet tulin maailmaan kuolleelta näyttävänä, ja ainoastaan monin puuhin ja ponnistuksin saatiin asiat sille kannalle, että näin päivän valkeuden. (Goethe 1956,8.)

Goethen suhtautuminen syntymäkartan tähtiin ei poikkea mitenkään olennaisesti edellä esitetyistä antiikin esimerkeistä. Goethen kuvaus on moderni, realistisempi ja yksityiskohtaisempi, mutta yhtä kaikki se on kuvaus tähditetystä ihmesyntymästä ja luo Ciceron syntymän tavoin "ihmeelliseen" ja onnekkuuteen viittaavan merkityspohjan Goethen elämälle ja sen merkityksellistämiselle.

Virallisen kertomuksen mukaan syntymätähdet (ja kohtalousko) siirretään Goethen ja muiden romantikkojen jälkeen epätieteellisinä asioina marginaaliin, mutta käytännössä asiat lienevät toisin. Elämäkerroille ja omaelämäkerroille ei ole modernissakaan kulttuurissa asetettu (historia)tieteellisiä vaatimuksia, vaan ne on - muistelmakirjailijoiden päinvastaisista vakuutteluista huolimatta - yleensä mielletty runoilijan vapauden ja vastuun alaiseksi tiedon alueeksi: (kauno)kirjallisuudeksi. Syntymäkertomus, tähtikarttoineen tai ilman sitä, on kuitenkin säilyttänyt (post)modernissakin kulttuurissa asemansa tärkeimpien eksistentiaalisten kysymysten heijastuspintana (vrt. Lejeune 1986, 313). Eräät 1900-luvun jälkipuoliskon merkit ja vuosituhannen vaihteen $\mathrm{New}$ Age -kulttuurin piirteet osoittavat, etteivät tähtikartat ole kadonneet minnekään.

\section{Tämä syntyminen ja varsinainen syntyminen}

Myöhäisantiikin ja keskiaikaisissa (auto)hagiografisissa teksteissä (kr. hagios = pyhä) eli pyhimysten (oma)elämäkerroissa inhimillisellä ja biologisella syntymällä on mitätön tai marginaalinen asema. Pyhimys(oma)elämäkerrat ovat pitkälle konventionaalisia kertomuksia, joissa elämänkulun jäsennys noudattaa vakiintuneita ja hyväksyttyjä Imitatio Christi -malleja (Weintraub 1975; Heffernan 1988). Merkityksellisempää kuin ihmisen lihallinen syntymä on henkinen syntyminen eli astuminen Kristuksen seuraamisen tielle. Tällaisia ovat kertomus syntymäkasteesta tai kääntyminen kristinuskoon. Hagiografioissa syntymäkertomus on siis symbolinen, ja se esitetään käännekohdan figuuria käyttäen ja tavalla, jossa mallia haetaan tunnustetuilta kristillisiltä auktoreilta, esimerkiksi Paavalin kääntymystarinasta (Apostolien teot) ja myöhemmin Augustinuksen Tunnustuksista (Kosonen 2002).

Varhaiskeskiaikaista historiallista tietoisuutta pohjaa ajatus ihmisen tämänpuo- 
leisen elämän ja kuunalisen maailman muodostamasta merkityksettömästä väliajasta (contemptus mundi), joka kuitenkin on Jumalan työtä ja hänen ohjauksessaan ja määräysvallassaan. Kristityille historia on lineaarista: alku on Luomiskertomuksessa ja loppu Kristuksen toisessa tulemisessa. Tällainen historiaymmärrys jäsentää sekä historiankirjoitusta $^{6}$ että pyhimyselämäkertoja, joissa historian esittämisen lainalaisuuksiin kuuluvat yhtä hyvin pyhimyksen tämänpuoleisen elämän tapahtumat (syntymä ja kuolema; kääntymyskertomus) kuin tuonpuoleiseen viittavat (ihme)teot ja -tapahtumat, jotka modernin historiantutkimuksen näkökulmasta eivät kuulu historiankirjoituksen piiriin.

Otan myöhäisantiikin ja keskiaikaisen kristillisyyden välimaastosta esimerkiksi kreikkalaisen piispan ja oratorin, teologiksi kutsutun kirkkoisän Gregorius Nazianzilaisen (n.329-n.390) omaelämäkerrallisen runon $\left(\right.$ Bios $\left.^{7}\right)$. Kyse on jambisella trimetrillä kirjoitetusta 2000 säkeen runosta, jonka temaattinen fokus on tekijän kristillisen elämäntarinan kokonaisuudessa: kuunalisen elämän loputtomien kurjuuksien sarjassa. Teoksen synty on ajoitettu vuosiin 382-389, jolloin yli 50-vuotiaan Gregoriuksen mieltä kalvoi elävästi vuoden 381 ekumeenikonsiili ja siihen liittyvät tapahtumat ja kokemukset. Ne olivat johtaneet Gregoriuksen yllättävään lähtöön Konstantinopolista ja asettumiseen takaisin kotiseudulleen Kappadokiaan, jossa hän saattoi viimeinkin omistautua halajamalleen elämäntavalle: kirjallisuudelle ja kirjoittamiselle. Käännekohdan seurauksena Gregorius katsoi tarpeelliseksi jäsentää koko maallisen elämänsä kulku aivan alusta asti: "Minä synnyin” (Grégoire de Nazianze 1960, 33):

Astuin siis tähän elämään kurja raukka maan mudasta muovattuna ja liittyneenä ruumiiseen, joka hallitsee meitä, ellemme me vaivalla ja työllä hallitse sitä. Syntymäni oli kuitenkin minulle vakuus kaikkein kauniimmasta; mukaudun siihen, sillä minulla ei ole oikeutta olla kiittämätön. Alusta asti kuuluin Toiselle - ihmeellisen lahjan kohteena: minut uhrattiin Jumalalle kuin hellästi rakastettu karitsa tai vasikka, kuin järjellä rikastettu jalo uhri. Uskaltaisin melkein sanoa: kuin uusi Samuel, ellen ottaisi huomioon kuin niiden toiveen jotka antoivat minut Jumalalle. (Grégoire de Nazianze 1960, 33; suomentanut Päivi Kosonen ${ }^{8}$ )

Gregoriukselle lihallinen syntymä merkitsee siis astumista tämänpuoleiseksi elämäksi kutsuttuun kurjuuteen. Kyse on raskaasta välivaiheesta, mutta Gregoriuksen on sopeuduttava, sillä se on Jumalan tarkoitus. Ihminen seuraa jumalallista kosmologiaa Jumalan tahdon mukaisesti, mutta voi myötävaikuttaa siihen omalla tahdollaan. Tämänpuoleista elämää seuraa joko ikuinen elämä tuonpuoleisessa tai kadotus sen mukaan, miten ihminen on elänyt.

Myös modernissa kristillisessä omaelämäkerrassa kirjaimellinen ja symbolinen, lihallinen ja henkinen syntymä liitetään yhteen tällaisessa perikristillisessä hengessä. Cornelia Jacobshagenin omaelämäkerrassa Valoa ylhäältä kristillisen kirkkovuoden 
määräämä elämänkulku ja oma elämä sulautuvat yhteen omasta syntymästä lähtien:

Minä, Kornelia Jokunto, olen syntynyt armon vuonna 1812, ensimmäisen adventtisunnuntain aamuna, seurakunnan laulaessa läheisessä P. Ansgariuksen kirkossa [--]. Tähän 'suruisaan laumaan' kuuluin jo minäkin, koskapa synnyin tähän maailmaan surkeasti itkien. Mutta tämä laulunpätkä on minulle koko elämäni ajan ollut erittäin rakas ja kallis, ja tätä olen aina pitänyt tervetuliaislaulunani. / Koska olen syntynyt ensimmäisenä adventtina, on syntymäpäivääni aina myöskin vietetty adventtisunnuntaina, päivämäärää huomioon ottamatta; ja siitä todennäköisesti on johtunut se, että lapsuudesta asti olen enemmän pitänyt kirkkovuodesta kuin tavallisesta vuodesta. (Jacobshagen $1910,5$.

Samoin kuin Gregoriusta, Corneliusta lohduttaa mahdollisuus kiinnittää tämä maallinen elämänsä syntymässään kristillisen Jumalan suureen kertomukseen ja kristilliseen kosmologiaan.

\section{Tämänpuoleistakin syntymää rehabilitoimassa}

Renessanssikulttuurissa, jossa tämänpuoleinen elämä ja inhimillinen saavat taas positiivisemman arvolatauksen, maallisesta syntymäkertomuksesta tulee ymmärrettävästi tärkeä. Renessanssiajan omaelämäkertojat tekevät tunnetusti huolellisesti selkoa omasta genealogiastaan, selittävät tarkoin oman syntyperänsä ja sukupuunsa, johon juuri syntymä heidät liittää.

Näin esimerkiksi oman arvonsa tunteva firenzeläinen kultaseppä ja kuvanveistäjä Benvenuto Cellini (1500-1571) kertoo omaelämäkerrassaan kokeneensa olleensa syntymästään asti tervetullut (it. benvenuto = tervetullut) poika, eikä siis olekaan ihme, että samainen Benvenuto 58-vuotiaana kuvataiteilijana kertoo jo jonkin aikaa tunteneensa halua alkaa kirjoittaa omin käsin omaelämäkertaansa ja pyrkiä näin tuottamaan kunniaa uljaalle firenzeläiselle suvulleen (Cellini 1933/1996, 9-10) ${ }^{10}$ :

Ja tapahtui, että hän sai lapsensa pyhäinmiesten päivän jälkeisenä yönä puoli viiden aikaan, tasan vuonna 1500 . Kätilö, joka tiesi talossa odotettavan tyttölasta, pesi lapsen, kietoi sen kauniiseen valkoiseen kapaloon, astui sitten aivan hiljaa Giovannin, minun isäni, luo sanoen: "Minä tuon teille kauniin lahjan, jota te ette ole odottanut." Isäni, joka oli todellinen filosofi, asteli edestakaisin ja sanoi: "Minkä Jumala minulle antaa, se on minulle aina mieluista", ja avatessaan kapalot hän näki odottamatta pojan. Hän löi yhteen vanhat kätensä, kohotti silmänsä taivasta kohti ja sanoi: "Herra, minä kiitän sinua kaikesta sydämestäni. Tämä on minulle hyvin rakas, olkoon hän tervetullut!” Kaikki läsnäolijat kyselivät häneltä iloisina, minkä nimen hän antaisi pojalle. Giovanni vastasi vain: “Olkoon hän tervetullut!” Ja niin päätettiin minulle pyhässä kasteessa antaa nimi Benvenuto [=tervetullut], jota nyt Jumalan armosta olen pitänyt koko elämäni ajan. (Cellini 1933/1996, 14.)

Cellinin syntymäkertomuksessa (samoin kuin koko omaelämäkerrassa) renessanssin henki - paluu antiikkiin - sekoittuu keskiaikaiseen kristilliseen kuvastoon. Cellinin 
syntymäkuvauksesta on vaikea tyhjentävästi erottaa roomalaiseen vitaan ja kristilliseen evankeliumikerrontaan kuuluvia aineksia, niin sekoittuneita ne ovat. Lopputulos on joka tapauksessa renessanssihenkinen syntymäkertomus, jossa syntyy poika ja koittaa uusi aika.

Ranskan vallankumouksen ja romantiikan uudet lapset Jean-Jacques Rousseau ja George Sand eivät hekään jätä mainitsematta inhimillistä syntymäänsä ja sen uutta merkityspohjaa. He ovat syntyneet uudella tavalla legitiimisti: kansalaisista ja kansalaisiksi, yhtä aikaa samanlaisiksi ja erilaisiksi kuin muut. Rousseau, jonka Tunnustusten (1938; Les Confessions 1782-89) tutkimuskohteena on oma ainutlaatuinen erityisyys ja sielun historian pienimmät ja salaisimmatkin säikeet, ohittaa kuitenkin inhimillisen kansalaissyntymänsä pakollisella lyhyellä maininnalla: "Olen syntynyt Genevessä vuonna 1772 kansalaisesta Isaac Rousseausta ja kansalaisesta Suzanne Bernardista" (Rousseau 1938, 8).

George Sandin omaelämäkerrassa Histoire de ma vie (1854-55) olennaista on onnekas syntymä tunnustetuksi tai lailliseksi tyttäreksi (fille légitime). Tyttären tunnustaminen on kokonaisuudessaan Sandin omaelämäkerrassa kuvattu tavalla, jota tekee mieli tulkita uuden naiskansalaisen ideaalisyntymäksi, mutta yksin syntymäkuvaus valaisee Sandin elämän ja tuotannon keskeistä pohjateemaa: erilaisten asioiden ja puolien yhteensaattamista. Omalla syntymällään hän yhdistää äitinsä talonpoikaissäädyn ja isänsä aatelisperinnön:

Viides heinäkuuta vuonna 1804 tulin maailmaan isäni soittaessa viulua ja äitini pitäessä kaunista vaaleanpunaista pukua. Se tapahtui silmänräpäyksessä. Minulla oli ainakin sen verran onnea matkassani, kuten tätini Lucie enteellisesti totesi, etten pakottanut äitiäni kärsimään pitkään. Tulin maailmaan laillisena tyttärenä, mikä olisi aivan hyvin voinut jäädä tapahtumatta, ellei isäni olisi päättäväisesti uhmannut perheensä ennakkoluuloja, ja se oli myös onni, sillä ilman sitä isoäitini ei ehkä olisi huolehtinut minusta niin rakastavasti kuin hän sitten myöhemmin teki, ja olisin jäänyt kokonaan vaille tuota pientä ideoiden ja tietojen lähdettä, joka on ollut lohdutuksenani elämäni ikävyyksissä. (Sand 1945, 17; suomentanut Päivi Kosonen) ${ }^{11}$

George Sand tuo syntymäkuvaukseen aivan uutta naisnäkökulmaa, joka ilmenee näinkin pienessä esimerkissä naisten ja naiselämän puolien esiin nostamisessa, esimerkiksi realistisena kuvauksena (tyttö)lapseksi tunnustamisen vaikutuksista. Isoäiti esitetään omakohtaisesti elävänä, vaikuttavana ja rakastettuna henkilöhahmona, ei pelkästään suuren ja kuuluisan ihmisen tarpeellisena statistina tai taustatekijänä.

\section{0-Iuvun modernit ja myöhäismodernit}

1900-luvun syntymäkertomuksesta puhuminen on harhaanjohtavaa siinä mielessä, että kyse ei useinkaan ole kertomuksesta, vain lyhyestä kuvauksesta tai jonkinlaisesta mininarratiivista. Ranskalainen kirjailija Georges Perec (1936-1982) esittää asian 
omassa muistikirjamerkinnässään, joka on myöhemmin julkaistu nimellä "Je suis né" (1988/1990, “Olen syntynyt”) seuraavasti: "On vaikea kuvitella tekstiä, joka alkaisi näin: Olen syntynyt. Mutta päivämäärän tarkennuksen jälkeen voi heti pysähtyä: Olen syntynyt 7. maaliskuuta 1936. Piste." (Perec 1988/1990, 9-10.) Suuri osa 1900-luvun omaelämäkertojista kertoo oman syntymänsä tällä tavoin: lyhyesti, kuin jonkinlaisena pakollisena ilmoitusasiana. Ja näinhän Perec teki itsekin kokeilevassa omaelämäkerrassaan W eli lapsuudenmuisto (1991; Wou le souvenir d'enfance, 1975):

Synnyin lauantaina 7. Maaliskuuta 1936 yhdeksän maissa illalla Pariisissa 19. kaupunginosassa sijaitsevalla synnytyslaitoksella, osoitteessa rue de l'Atlas 19. Luulen, että juuri isäni teki syntymäilmoituksen. Hän antoi minulle ainutlaatuisen etunimen - Georges - ja ilmoitti, että olisin ranskalainen. (Perec $1975 / 1991,11$.

Tällaisen lakonisen esitystavan voi ajatella heijastavan 1900-luvun omaelämäkerran todenvastaavuuden periaatetta - ajatusta, jonka mukaan emme muista omaa syntymäämme, emmekä voi kuvata sitä yksityiskohtaisesti.

Mutta on oikeita kertomuksiakin, yksityiskohtaisesti ja eloisasti kuvattuja syntymätarinoita. 1900-luvun omaelämäkertojat saattavat kuvata yksityiskohtaisesti syntymää edeltävää kohtuaikaa, kertoa syntymisestään (ahtaasta tunnelikokemuksesta) tai selostaa syntymätapahtuman jälkeistä sylivauva-aikaa. Näihin inhimillisen elämän varhaisvaiheisiin - kohtu, syntymä, sylivauva-aika - liittyvät kertomukset voivat olla ja usein ilmeisesti ovatkin psykoanalyyttisen tai vastaavan terapiaprosessin virittämiä muistoja. Varhaislapsuuteen liittyvä aika tulee helposti jokaisen omaa elämäänsä muistelevan ihmisen mieleen: onhan omaelämäkerrassa aina tietty psykoanalyyttinen ja (itse)terapeuttinen aspekti mukana (ks. L'autobiographie 1987). Tällaiseen terapian ja itseterapian yhteyteen esimerkiksi Claes Andersson liittää oman uudelleen syntymisen kokemuksensa kirjassaan Luova mieli (2002).

Ranskalais-venäläisen kirjailijan, Nathalie Sarrauten (1900-1999), modernistishenkisessä omaelämäkerrassaan Lapsuus (1984; Enfance 1983) esittämä allegorinen syntymäkertomus on eloisasti ja yksityiskohtaisesti esitetty kertomus. En mene tässä tarkemmin Sarrauten symbolisen syntymäkertomuksen yksityiskohtiin, joita olen analysoinut muussa yhteydessä, samoin kuin Georges Perecin, Marguerite Durasin ja Alain Robbe-Grillet'n omaelämäkerrallisia syntymäkertomuksia. Olennaista näissä (post)modernejakin piirteitä omaavissa syntymäkertomuksissa on niiden tapa ulottaa tekstuaalisuus omaan syntymään asti. (Kosonen 1999; Kosonen 2000).

\section{Muistettu ja unohdettu syntymä}

Philippe Lejeune on tarkastellut artikkelissaan "Récits de naissance" (1986) Freudin ja psykoanalyysin ajan jälkeistä psykoanalyyttistä kertomustyyppiä, jossa syntymästä 
tehdään fantasmaattinen projektioiden paikka, persoonallisuuden alkuperä tai henkilökohtaisten traumojen perimmäinen syy. Olennaista tässä yhteydessä on Lejeunen ajatus, jonka mukaan syntymän psykodraama on alkanut muodostaa kokonaan uuden syntymän kertomisen tavan ja uuden syntymäkertomuksen todenvastaavuuden, jonka mukaan oma syntymä voidaan omaelämäkerrassa kertoa eloisasti ja yksityiskohtaisesti. (Lejeune 1986, 321). Esimerkiksi voisi ottaa vaikkapa Alain Robbe-Grillet'n kokeellisen omaelämäkerran Miroir qui revient (1984) (ks. Kosonen 1999; Kosonen 2000, 122-125)

Tällaisen 1900-luvulle tyypillisen uudenlaisen fabuloinnin ja erilaisten mielikuvituksellisten syntymätarinoiden rinnalla esiintyy tietenkin myös (itse)reflektiivistä ja analyyttistä pohdintaa - yritystä muistaa ja pohtia, miksei muista. Toisaalta syntymän muistamattomuuden pohtiminen on sekin tapa kertoa oma syntymä.

Saksalainen kirjailija E.T.A. Hoffmann vei aikoinaan muistamattomuusmotiivin äärimmilleen parodisessa pastissiromaanissaan Kissa Murr (1946; Kater Murr 182022), jossa kissan (!) kyvyttömyys muistaa omaa syntymäänsä tuottaa huvittavan syntymäkertomuksen. Lainauksessa kannattaa kiinnittää huomiota erityisesti syntymän esittämisen romanttisiin konventioihin:

Elämänhän läpäisee ja saa, tietämättä itsekään, kuinka. Ainakin minun on käynyt niin, eikä kuulemma yksikään ainoa ihminenkään maan päällä tiedä omasta kokemuksestaan, missä ja miten hän on syntynyt, vaan ainoastaan perimätiedon perusteella, joka sitä paitsi on useinkin hyvin epävarma. Kaupungit kiistelevät suurmiehen syntymästä. Lopputulos on se, etten minä itsekään tiedä mitään ratkaisevaa, vaan olen ainiaaksi jäävä tietämättömäksi siitä, näinkö päivänvalon kellarissa, ullakolla vai puuvajassa, tai ei oikeastaan, näinkö, vaan ainoastaan, näkikö minut kallis äitini ensi kerran siellä vai täällä. Sillä kuten suvullemme on ominaista, olivat silmäni verhon peitossa. Aivan hämärästi muistan eräänlaiset murahtelevat ja pärskähtelevät äänet, jotka kaikuivat ympärilläni ja jollaisia minä melkein vastoin tahtoani päästän, kun viha minut valtaa. Selvemmin muistan itseni suljettuna hyvin ahtaaseen, pehmeäseinäiseen säiliöön, jossa tuskin pystyin hengittämään, ja hädässä ja tuskassa korotin ääneni surkeaan valitukseen. Tunsin, että jokin haparoi säiliön sisustaan ja kävi minuun kovakouraisesti käsiksi, ja täten minulle tarjoutui tilaisuus ensimmäisen kerran tuntea ja käyttää sitä ihmeellistä voimaa, jonka luonto on minulle lahjoittanut. Hyvin varustetuista karvapeitteisistä etukäpälistäni paljastin terävät, käyrät kynteni ja upotin ne siihen johonkin, joka oli tarrautunut minuun ja joka ei, kuten myöhemmin käsitin, voinut olla muu kuin ihmiskäsi. (Hoffmann 1946, 13.)

Kaikissa kulttuureissa ja kaikkina aikoina ajatuksessa syntymän muistamisesta ei kuitenkaan ole mitään naurettavaa. (Sitä paitsi voihan Hoffmannin irvailun kohteena olla pikemminkin nerojen itse-esitykset.) Psykoanalyyttisestä kertomustyypistä ja syntymän psykodraamasta oli jo aiemmin puhetta. Vastaavasti esimerkiksi Intiassa pyhien miesten ja askeetikkojen on ajateltu omaavan erityisiä henkisiä voimia, joiden avulla he saattoivat muistaa aikaisemmat syntymänsä. Buddhalaisuuden pyhien kirjoitusten 
joukossa on puolestaan erityinen Syntymäkertomusten (Birth Stories) nimellä tunnettu tarinakokoelma, joissa kerrotaan Buddhan 550 syntymästä eläimen, ihmisen ja jumalan hahmoon. (Misch 1907/1973, 86) Suomeksi näitä Jataka-tarinoita on luettavissa kokoelmassa Kun Buddha syntyi hanhen hahmoon (1998).

Muistamisen problematiikkaan liittyy myös modernin syntymäkertomuksen tavallisin kerrontatapa: vapaa epäsuora esitys (eläytymisesitys). Se on toisaalta esitystapa, jossa muistelevan kertojan diskurssi ja menneisyyden minän diskurssi ${ }^{12}$ liu'utetaan toisiinsa tarkoituksena luoda kerronnallinen välitila, jossa kysymyksen lausuman ja tiedon alkuperästä (“kuka puhuu?”) voi jättää poeettiseen hämärään. Toisaalta se on esitystapa, jossa muistelevan aikuiskertojan voi sanoa tavoittavan jotain menneisyyden minän (entisen itsensä) ajatus- ja elämysmaailmasta. Minun olisi siis uskottavampaa omaelämäkerrassani sanoa "Synnyin 12. marraskuuta 1962" kuin "Minulle on kerrottu, että synnyin 12. marraskuuta 1962", vaikka jälkimmäinen tapa on sananmukaisesti totuudenmukaisempi.

\section{Johtopäätöksiä}

Tässä käytetty syntymäkertomusten aineisto ei tue narratologisessa omaelämäkertatutkimuksessa esitettyä ajatusta modernin omaelämäkerran muodostamasta radikaalista katkoksesta suhteessa edeltävään kirjallisuuteen. Kovin pitkälle meneviä johtopäätöksiä ei näin suppean tarkastelun pohjalta voi tehdä, mutta radikaalista katkoksesta en niiden yhteydessä puhuisi. Päinvastoin näinkin pieni syntymäkertomusaineisto osoittaa mitä moninaisimpiin jatkuvuuksiin modernia edeltävän ja modernin omaelämäkerrallisuuden välillä. Historiallisia muutoksia on silti olemassa. Ne liittyvät minuuden merkityspohjan muutoksiin, siihen mitä "minun syntymäni” piirin milloinkin kuuluu.

\section{Viitteet}

${ }^{1}$ Kiitän saamistani kommenteista Kirsti Määttästä ja Johanna Materoa.

2 "Modernilla omaelämäkerralla" viittaan 1700-luvulla muotoutuneeseen kirjallisuuden lajiin, jossa yksilöihminen tekee tarinan eletystä elämästään ja oman persoonallisuutensa historiasta.

${ }^{3}$ Omaelämäkerta on useimmiten autodiegeettistä kerrontaa, jossa tekijä, kertoja ja päähenkilö viittaavat samaan henkilöön. Tekijä-kertojan käsite pohjaa Lejeunen

omaelämäkertanarratologiaan (ks. Lejeune 1975, 18).

${ }^{4}$ Kyse on siis keisarin henkilökohtaisesta muistelmateoksesta (27-22ekr), joka on säilynyt fragmentteina, ei hänen paremmin tunnetusta julkisesta testamentistaan Res Gestae Divi Augusti (12-14jkr).

${ }^{5}$ Esimerkiksi Edwin Linkomies suomennoksen (Suetonius 1960) johdannossa.

${ }^{6}$ Esimerkiksi Beden Historia Ecclesiastica (Ecclesiastical History of the English People) on Englannin kirkkohistoria ja samalla kertomus kristillisen uskon leviämisestä ja edistymisestä. (Heffernan 1988, 26-7).

${ }^{7}$ Sur sa vie. Ks. (Saint) Grégoire de Nazianze 1960. 
${ }^{8}$ J'entrais donc cette vie, pauvre être, hélas, tiré du limon de la terre et uni à un corps qui nous domine, si nous ne le dominons laborieusement. Ma naissance fut cependant pour moi le gage de tout ce qu'il y a de plus beau; j'en conviens, car je n'ai pas le droit d'être ingrat. Dès le début, j'appartins à un Autre, - objet d'un don magnifique: on m'offrit à Dieu, comme un agneau ou un veau tendrement aimé, comme une victime noble et enrichie de la raison. J'oserais presque dire: comme un nouveau Samuel, si je n'envisageais que le désir de ceux qui me donnèrent à Dieu. (Grégoire de Nazianze 1960, 33)

${ }^{9}$ Alkuperäisen teoksen ja ensimmäisen painoksen ajankohta on hämärässä, mutta se lienee 1800-luvun loppupuolella, jos Cornelia on syntynyt 1812. - Ks. Jakobshagen 1910.

${ }^{10}$ Cellini 1933/1996. - Vita di Benvenuto Cellini, scritta da lui medesimo. Benvenuto aloitti omakätisen käsikirjoituksen vuonna 1558, mutta antoi työn pian kirjurilleen, jolle saneli huikean seikkailullisen elämänsä myötä- ja vastamäet. Teksti julkaistiin ensimmäisen kerran vasta 1728 , jolloin tällaisille henkilökohtaisista elämänkäänteistä kertoville teksteille alkoi olla lukijakuntaa.

11 "Le 5 juillet 1804, je vins au monde, mon père jouant du violon et ma mère ayant une jolie robe rose. Ce fut l'affaire d'un instant. J'eus du moins cette part de bonheur que me prédisait ma tante Lucie de ne point faire souffrir longtemps ma mère. Je vins au monde fille légitime, ce qui aurait fort bien pu ne pas arriver si mon père n’avait pas résolument marché sur les préjugés de sa famille, et cela fut un bonheur aussi, car sans cela ma grand-mère ne se fût peutêtre pas occupée de moi avec tant d'amour qu'elle le fit plus tard, et j'eusse été privée d'un petit fonds d'idées et de connaissances qui a fait ma consolation dans les ennuis de ma vie." (Sand 1945, 17.)

${ }^{12}$ Vrt. Pekka Tammen $(1992,27-)$ KHD = Kertojan ja Henkilön Diskurssista.

\section{Lähteet}

ANDERSSON, ClAes 2002: Luova mieli. Kirjoittamisen vimma ja vastus. Helsinki: Kirjapaja $\mathrm{Oy}$.

L'autobiograhie 1987 = L'autobiographie. VIes rencontres psychanalytiques d'Aix-en-Provence 1987 par M. Neyraut, J.-P. Pontalis, Philippe Lejeune et al.. Paris: Société d'Édition 'Les Belles lettres'.

Cellini, Benvenuto i933/1996: Oma-elämäkerta. Porvoo et al.: Werner Söderström Osakeyhtiö.

goethe, Johann wolfgang von 1956: Tarua ja totta. (Aus meinem Leben. Dichtung und Wahrheit, 1811-33.) Valitut teokset III. Suom. J.A. Hollo. Helsinki: Otava.

(saint) GRÉgoire de nazianze i960: Sur sa vie. - Poèmes et lettres. Traduits par Paul Gallay et extraits de l'ouvrage publiée par les Editions Vitte, Lyon-Paris. Textes choisis et présentés par Edmond Devolder. Namur (Belgique): Les Editions du Soleil Levant. HefFernan, thomas J. 1988: Sacred Biography. Saints and Their Biographers in the Middle Ages. New York and Oxford: Oxford UP.

HOFFmanN, E.T.A. I946: Kissa Murr. Ja hänen elämänviisautensa sekä satunnaisia makulatuurikatkelmia kapellimestari Kreislerin elämäkerrasta. (Lebens-Ansichten des Katers 
Murr nebst fragmentarischer Biographie des Kapellmeisters Johannes Kreisler in zufälligen Makulaturblättern, 1820-22.) Suom. Teijo Havu. Helsinki: Oy Suomen kirja. JAKOBSHAGEN, C[ORNELIa] I9IO: Valoa ylhäältä. Varhain orvoksijääneen tytön muistelmia elämästään. Kahdeksannestatoista saksalaisesta painoksesta suomentanut Lyyli Vihervaara. Jyväskylä: K.J. Gummerus Osakeyhtiö. KOIVU, LEENA I982 (тоім.): Syntymä. Enteitä ja uskomuksia. Helsinki: SKS. Kosonen, PÄrvi I995: Samuudesta eroon. Naistekijän osuus George Gusdorfin, Philippe Lejeunen, Paul de Manin ja Nancy K. Millerin autobiografiateorioissa. Lisensiaattitutkielma. Yleinen kirjallisuustiede. Julkaisuja 27. Tampere: Tampereen yliopiston jäljennepalvelu.

KOSONEN, PÄIVI I999: Myöhäismoderni kokeileva omaelämäkerta: syntymään ulottuva teksti. Laulujen lumoissa. Kirjallisuudentutkijoiden ja kirjailijoiden seireenilauluja professori Yrjö Varpiolle hänen 60-vuotispäivänään 7.11.1999. Toim. Yrjö Hosiaisluoma. Tampere: Tampere UP.

KOSONEN, PÄIVI 2000: Elämät sanoissa. Eletty ja kerrottu epäjatkuvuus Sarrauten, Durasin, Robbe-Grillet’n ja Perecin omaelämäkerrallisissa teksteissä. Helsinki: Tutkijaliitto. (Ks. Luku: IV:2, Syntymään ulottuva teksti)

KOSONEN, PÄrVI 2002: Käännekohdan retoriikkaa. Hämärä ja kirkas omaelämäkerrallisessa kirjoituksessa. Kielen ja kirjallisuuden hämärä. Toim. Päivi Mehtonen. Tampere: Tampere UP, 110-130.

Kun Buddha syntyi hanhen hahmoon. Valikoima buddhalaisia Jataka-tarinoita 1998. Paalinkielisestä alkutekstistä suomentanut Virpi Hämeen-Anttila. Helsinki: Basam Books.

Lejeune, philippe 1971/I998: L'autobiographie en France. Deuxième edition. Paris: Armand Colin.

Lejeune, Philippe 1975: Le pacte autobiographique. Paris: Éditions du Seuil.

Lejeune, Philippe 1986: Le récit du naissance. Moi aussi. Paris: Editions du Seuil.

MARShall, GRegory I995: The Sound of Story. Narrative, Memory, and Selfhood. Narrative, Vol. 3, No. 1, January, 33-56.

MISCH, GEORG I 907/I 973: A History of Autobiography in Antiquity. (Geschichte der Autobiographie.) Vol. 1. Westport, Conn.: Greenwood Press.

PEREC, GeORGE I975/I99i: W eli lapsuudenmuisto. (Wou le souvenir d'enfance.) Suom. Päivi Kosonen. Helsinki: Like.

PEREC, GeORge I988/I990: Je suis né. Je suis né. Coll. Librairie du XXe siècle. Paris: Éditions du Seuil.

plutarkhos 1989: Cicero. Kuuluisien miesten elämäkertoja. Porvoo et al.: Werner Söderström Osakeyhtiö.

rousseau, JeAn-JACQUeS I 938: Tunnustuksia. (Confessions, 1782-89.) Valikoima ottei- 
ta. Suom. Edwin Hagfors. Jyväskylä-Helsinki: K.J. Gummerus Osakeyhtiö.

SAnd, GeORge i 854/1945: Histoire de ma vie. Préface de Jérome et Jean Tharaud de l'Académie francaise. Paris: Stock.

Sarraute, nathalie 1984: Lapsuus. (Enfance, 1983.) Suom. Annikki Suni. Helsinki: Otava. suetonius i960: Rooman keisarien elämäkertoja. Suom. J.A. Hollo. Johdannon kirjoittanut Edwin Linkomies. Porvoo ja Helsinki: Werner Söderström Osakeyhtiö. TAMMI, PEKKA I 992: Kertova teksti. Esseitä narratologiasta. Helsinki: Gaudeamus. weintraub, karl J. I975: Autobiography and Historical Consciousness. Critical Inquiry 1/4 June, 821-848. 